\title{
Deconstruction and Translation: Positions, Pertinence and the Empowerment of the Translator
}

\author{
Jennifer Varney \\ Bologna University
}

\begin{abstract}
This paper aims to present an overview of the theoretical positions adopted both within and beyond the translation community regarding the value of deconstruction to the practice and study of translation. In its examination of the arguments against the general pertinence of deconstruction to translation studies, it discusses the problem of the indeterminacy of meaning, the perceived lack of rigour associated with deconstructive practices and the 'anything goes' criticism levied against deconstructive readings of texts. It then goes on to look at the arguments favouring deconstruction as a pertinent theoretical framework for translation studies and evaluates the implications for translators of its emphasis on the interpretative process and the production of meaning. If the reader/translator is an active and empowered player in the interpretative process and thus adopts a key position in meaning production, the translator emerges as a creative text-producer possessing independent creative rights and powers. Given the increased visibility of the translator in these terms, we must now begin considering the nature of the creative rules and constraints which govern, delineate or constrain the translator's position. The paper concludes with a discussion of a particular example of a translator assuming creative responsibility,
\end{abstract}


and the textual and extra-textual implications of this choice.

Keywords: translation, deconstruction, interpretation, translator empowerment, meaning.

\section{Introduction : Deconstruction and Theory}

Any discussion regarding the value of deconstruction as a theoretical approach to translation must first grapple with the question of whether deconstruction can indeed be defined as theory. Derrida was eager to point out that deconstruction should be seen as a system; indeed in a note appended to the bibliography of the first French edition of Writing and Difference, he describes the essays collected in this book in the following terms: "What remains here the displacement of a question certainly forms a system" (Derrida 1978: xiii). Later on he employs the metaphor of sewing as a way of shedding light on the activity of deconstruction, where Derrida's texts are sewn (or, more appropriately, basted) onto the textual material of his discourse: "If text means cloth, all these essays have obstinately defined sewing as basting” (Derrida 1978: xiii). Again, in his 'Letter to a Japanese friend', he states that deconstruction is not a form of analysis, not a critique, nor a method in the traditional philosophical understanding of these terms (Wood and Bernusconi, 1985: 3). Following this assertion, various scholars have taken the argument a step further, questioning whether the humanities in general and translation specifically can/should be viewed as an object of theory (Steiner 1973, de Man 1982, Arrojo 1998). The word 'theory' derives from the Greek word, theorein, meaning to gaze upon, to look at. Hidden in the roots of this word is an implied hierarchical structure which posits an external, authoritative gazer (subject) in a unidirectional power relationship with the internal, passive object. Looking and the gaze can be associated with the 
epistemological urge which locates the drive for knowledge alongside the drive for power. Arrojo reminds us that this drive is informed by what Nietzsche has called "the pathos of truth" (Arrojo 2002: 64), which seeks possession and control via the fixing of phenomena in a finite, univocal structure. Thus the term 'theory' is itself at odds with deconstruction which, through its insistence on différance, subverts the binary logic of subject/object and undermines the existence of fixed, finite 'truths'.

\section{Différence and Plurality}

Developing Saussure's claim that meaning in language is a matter of difference, Derrida finds that there is no harmonious correlation between the level of signifiers and the level of signifieds in a language and that meaning is scattered and dispersed along an infinite chain of signifiers. The play of difference implied by this dispersal is signalled by Derrida's notion of différence which in English suggests the notions of differing, differentiating and deferring. "Play", says Derrida, "is always a play of absence and presence” (Derrida 1978: 292); thus meaning cannot be said to be immediately present but must also depend on that which is absent. Given that language is a temporal process (Steiner 1975), meaning will always be deferred, or "still to come" and is thus never selfidentical because whilst signs are always repeatable, repetition can only take place in a new context which in turn alters meaning. Language is therefore a signifying system in which signifiers refer to each other in an infinite circular process of meaning production. Meaning is a product of the text and neither precedes nor exists beyond the text: "There is no outside-the-text” (Derrida 1989: 841). The notion of différance thus informs all signs, including the subjective-I sign, with the result that "Pure I, identical to I-self, does not exist. I is always in difference..." (Cixous 1994: 18). To 
deconstruct a text is therefore to discover its plurality, to open it and to "release all the possible positions of its intelligibility" (Belsey 1980: 109).

Fundamental to the notion of difference, as Alan Bass points out in his translator's introduction to the English edition of Writing and Difference, is its link to the ideas of totalitarianism and solicitation (Bass 1978: xvi). Derrida sees structuralism as a form of totalitarianism to the extent that it seeks to explain the totality of a text or concept by making that text or concept respond totally to a formula or theory that governs it. Derrida's answer to this totalitarian project is to expose it to solicitation, a word deriving from the Latin sollicitare meaning to shake the totality. "Every totality, [Derrida] shows, can be totally shaken, that is, can be shown to be founded on that which it excludes, that which would be in excess for a reductive analysis of any kind" (Bass 1978: xvi). This of course is of great pertinence to any discourse on the activity of translation, and should be kept in mind especially when evaluating certain forms of non-conformist translation practices, such as those outlined below in the discussion of political translation. If totalitarian readings of texts are reductive, we must begin to reconsider traditional notions of translator fidelity (to the source text / source author) as well as the traditionally hierarchical relationship between source and target text, which posits that the ST is inherently inferior to the 'original'. Indeed, Derrida encourages us to think in terms of the "impossible presence of the absent origin” (1978: 292) and this leads him to make several comments on the notion of play. There is a negative, nostalgic and guilty (Rousseauistic) form of play which mourns the lost centre, and facing this, a play of affirmation (Nietzschean) which revels in the play of becoming in a world of signs offered up to active interpretation. "This affirmation then determines the noncentre otherwise than as loss of the centre" (1978: 292). Affirmation plays without security. "For there is a sure play: that which is limited to the substitution of given and existing, present, pieces" (1978: 292). 
Ideas such as this must clearly change the way we think and talk about translation. If translation is a form of reading activity, certainly a form of interpretation, then it too is referenced by Derrida's comments on the notion of play. And we might suggest that the ideas of safe play and non-safe play also nudge us toward a looser, more inclusive rather than exclusive, understanding of what translation can and should be. The feminist and political translation examples discussed below would seem to challenge the notion of translation as the mere substitution of given meanings, and tap (consciously or unconsciously) into the idea of non-safe play where translation is no longer a form of linguistic exile mourning the loss of the original. Moreover, with Derrida's deconstruction of the notion of origin, translation can no longer be seen as occupying a lower position in some generalised hierarchy, but instead is woven, sewn, or basted onto the source text it flanks and thus exists in a form of dialectic relationship that presages dialogue between the ST and the TT.

\section{The 'General Pertinence' of Deconstruction to Translation Studies}

Critical approaches to translation analysis have been undeniably influenced, both positively and negatively, by ideas such as the play of signifiers, meaning as product of text, and the unstable source. Translation scholars would almost certainly have taken up the critical positions associated with these ideas without the help of Derrida or deconstruction, and Pym might be hinting at something similar when, in questioning the "general pertinence of deconstruction", he states that "no translator or translation critic need believe that translation is the transfer of stable meaning" (Pym 1995: 14). The ideas that we associate with deconstruction cannot be said to 'belong' to deconstruction, (nor would deconstruction accept 
this notion of property); indeed deconstruction is not the only route leading from Modernism's thwarted hope in meaning to Postmodernism's hopelessness in the face of meaning, yet it certainly is the quickest route, and in an age of utilitarian instrumentalism, methods must respect the exigencies of speed, economy and efficiency. Thus, when referring to the implications of deconstruction, it is in full awareness that ideas can be neither fully owned by nor attributable to any stable, fixed source.

Barthes, confusingly referred to by critics as both a structuralist (Culler 1983) and post-structuralist (Eagleton 1983, Lodge 1988), insists that to interpret a text does not mean to give that text a single meaning, but to appreciate the plurality contained within it (Barthes 1970: 11). Plurality of meaning and the rejection of any notion that texts might conceal unitary, univocal truths have long been the currency of translation studies (Benjamin 1955, Steiner 1975, Arrojo 1994, Pym 1995, Chau 1984, Jones 2004) although as recently as 1976 literary criticism was having to answer to the claims of critics such as E.D. Hirsch who were arguing that the 'meaning' of texts was objectively knowable and distinguishable from the significance attributed to that meaning by particular readers (Hirsch 1976). In a similar vein, Abrams states that the "deconstructionist reading of a given work is plainly parasitical on the obvious or univocal reading" (1976: 457). What is at stake here is the idea that deconstruction relies on the search for original meaning in order to release the play of difference and that it thus reaches difference "by a process which, in its way, is no less dependent on an origin, ground, and end, and which is no less remorselessly 'teleological' than the most rigorous of the metaphysical systems that [Derrida] uses his conclusions to deconstruct." (Abrams 1977: 431) This of course is a fair criticism, though we should not confuse means with ends; deconstruction's 'search' might be fuelled by a similar epistemological drive to that of any essentialist 'search', but where the latter seeks 'end' in a finite structure, the former holds out no hope of revealing 'origin' or 
'end'. Moreover, deconstruction's unpicking of the 'metaphysical systems' mentioned by Abrams should not be equated with a rejection of historical concepts; indeed, Davis guards against jettisoning concepts in general since these have structured our history of thought (Davis 2001) and Spivak argues from a similar perspective when she points out that what deconstruction seeks to question is not the historical concept itself but the way in which that concept has been produced:

"Deconstruction does not say there is no subject, there is no truth, there is no history. It simply questions the privileging of identity so that someone is believed to have the truth. It is not the exposure of error. It is constantly and persistently looking into how truths are produced” (Spivak 1994, cited in Davis 2001: 46).

The way we think about translation clearly benefits from elucidations of this sort which undermine the claim that univocal truths and 'right' interpretations exist. Spivak's pragmatic approach to deconstruction's questioning of identity can be extended to the discussion of translation practices that also seek to question the identity of the source text by a form of translational commentary or critique which adopts a very specific and responsibility-laden subject position vis-à-vis the source text. For this really is what we are talking about: a form of translation which goes beyond the simple substitution of one language by another, but a form of textual practice which seeks in some way to re-express the meanings of the source text whilst adopting, through the lexical or syntactic reworkings characteristic of translation in general, a definite critical subject-position. On a very basic level, any interpretation must in some way imply the adoption of a subject position. Thus translations (privileged interpretations) which highlight the authorship of the translator, i.e., those translations where the translator is visible 
rather than invisible and his/her voice is apparent rather than mute, respond to the logical exigencies of any interpretative act and should not be seen as the bastardization of the translator's role or the usurpation of textual authority. Translations of the sort carried out by Francis Jones and discussed below, certainly require that we keep in mind this notion of translation as simultaneously (and necessarily) producing a form of critical commentary on the text translated and the ideas it contains. Translation is obviously a form of writing and writing always entails some degree of manipulation; yet it is not free of ideology and this ideological position-taking. When considered form this perspective, questions of textual ownership and the creative freedom and/or responsibility of the translator emerge as highly pertinent themes.

Before this issue is examined in greater depth, let us for a moment return to the question of pertinence. One of the principle criticisms aimed at deconstruction, a criticism which is not limited to Translation Studies but echoes throughout various interdisciplinary debates, is its perceived lack of rigour. Eco, for example, opposes reader-oriented theories which allow for any type of reading where any can stand for all (Eco 1995: 169). In an attempt to curb reading strategies over-eager to create relationships of likeness between everything and anything, he proposes an 'economy' of interpretation which would serve to guarantee the pertinence of all associations drawn and which would invalidate what he calls 'bad' and 'forced' interpretation (Eco 1995). Eco nails his colours to a 'third way'; in rejecting both reader- and authororiented interpretative strategies, he suggests that the intentionality of the text should guide the interpretative process: a text should be held up as a parameter for the readings it produces (Eco 1990: 35). This position is, however, similar to that previously adopted by Barthes (1970) and Iser (1978); and in the end, it does little to undermine deconstruction's approach to interpretation as it can effectively be subsumed into Derrida's irrefutable claim about the 
non-existent 'outside-the-text'.

Closely linked to the 'anything goes' critique of deconstruction is the complaint that deconstruction's stress on the indeterminacy of meaning makes interpretation pointless. De Man argues against this absolutist position when claiming that, despite the traditional desire to draw connections between world and book being doomed, to claim that this is a sufficient reason not to envisage doing literary theory is akin to rejecting anatomy because it in unable to cure mortality (De Man 1982).

The claim that interpretation produces text is corroborated by Arrojo's study of Nietzsche's theoretical position: "Nietzsche's notions of textuality point to a conclusion that there is no text in itself apart from the activity of interpretation” (Arrojo 2002: 65). If this is so, then the reader is evidently responsible for the construction of meaning and this notion has significant implications for the translation activity. If, as Gadamer claims, there is something absurd about the idea of a uniquely correct interpretation (Gadamer 1975) the translator-as-reader need no longer be bound by the absurd requirement of fidelity towards the 'real meaning' of the source text, and can thus assume a more empowered role in the transformation of meaning for the target culture. As Davis claims, "the instability of the signifier, the multiplicity of textual interpretations, and the incommensurability of translation, are precisely what disrupts the original/translation hierarchy" (Davis 2001: 43). With the break-down of this binary relationship, the translator emerges as a creative text-producer possessing independent creative rights and powers.

Recent debate in translation studies has focussed not so much on whether the translator is a creative, performative figure (which is now taken for granted), but rather what it is that constrains or should constrain such creativity (Arrojo 1994; Von Flotow 1997; Hermans 1999; Jones 2004). Jones arguably encounters a limit when he mentions the possibility of adopting translational strategies aimed at 
'downgrading' the work of what he calls "evil poets" for political ends (Jones 2004). Arrojo, for her part, has criticised feminist translators' appropriation of the notion of 'abusive fidelity'. This term was originally used by Lewis to refer to a situation where the target text refuses to adapt to target culture norms and remains as faithful as possible to the ST in order to produce a foreign-sounding text that will sound strange to readers (Lewis 1995). Venuti claims that such a strategy leads to "translation's liberating moment” which occurs when the reader of the resistant translation experiences, in the target language, the cultural differences which separate that language from the foreign text (Venuti 1991). According to von Flotow (1997), Arrojo's criticism of abusive fidelity particularly regards those feminist translations that wilfully subvert the source text for their own political ends. Whilst few would disagree with Folkart when she argues that translators cannot help but feed their own interests into their texts, (Folkart, cited in Lane-Mercer 1991: 48), De Lotbinière-Harwood's feminising of masculine pronouns in her translation of Lise Gauvin's Lettres d'une autre (cited in Von Flotow 1997) might be seen as taking a step too far in the political manipulation and instrumentalization of the source text. For Arrojo, the principle of 'abusive fidelity' as used by certain feminist translators is self-contradictory to the extent that one cannot claim fidelity to a text one is trying to subvert. Von Flotow in turn argues that these translators see themselves as operating in a close relationship with a text which, by its very nature, is 'subversive' and this consequently licences their 'creativity' (ibid.). Clearly the issues of whether, how and why translator-creativity should be constrained raise complex questions and have yet to be fully addressed by the translation studies community. 


\section{Creative Responsibility and Ethical Constraints}

Jones' (2004) examines the way in which issues of loyalty, ethics and ideology condition the position of a literary translator and his participant-interpreter study discusses his own role as literary translator from Bosnian-Croatian-Serbian during the wars of Yugoslav succession in the 1990s.

Central to Jones' study is the notion that translating, like writing, cannot take place in a socio-ethical void. Translators are social as well as textual players and the personal, ethical and political exigencies of the context in which they work cannot be overlooked. The translator's ethical dilemma arose from his sense of personal loyalty towards the Bosnian people and culture which he believed he had a moral duty to defend. The decision not to remain neutral in his relationship to the source text and thus to instrumentalise translation had various implications for him, the most radical of which were his decision to 'improve' the 'literary quality' of 'sub-standard' Bosnian verse in order to promote a positive image of Bosnian culture, and his discussion of whether or not it would have been acceptable to 'downgrade' through translation the poetry of figures such as Radovan Karadzic.

Decisions of this sort, where loyalty to the source text is relegated to second place behind the translator's own personal political or ideological agenda, challenge our assumptions about the power hierarchy that positions text, author and translator. Jones assumes for himself more that just the gate-keeping role of deciding what sort of texts pass from source to target culture. In his discussion of improving or downgrading texts though translation, he situates the translator alongside editors, agents and critics, figures to whom society traditionally allocates the responsibility of collectively assessing the worth of literary figures and literary texts. But whilst this on the one hand awards the translator a level of 
power and visibility that he/she undoubtedly deserves, it does little to raise the level of trust bestowed on those same translators by authors, readers, editors, critics, literary agents etc. Moreover, for the translator to assume this degree of power, i.e., to claim the right to absolute judgement over the supposed worth of a particular literary work, is to remove the possibility of that work and its author receiving a fair hearing. Nor does it show much faith in the reader who is presumably not responsible enough to exercise their own critical judgement when assessing the value of a text. Intervention of this sort is dangerous and risks undermining the translation profession, and yet at the same time we cannot overlook the fact that the translation process inevitably involves a certain degree of alteration or change, both conscious and unconscious on the part of the translator.

So where do we draw the line? It is important that we accept that translators are not neutral figures insofar as they cannot sever themselves from the very socio-cultural, ideological and ethical influences that identify them. Yet nor would we want a situation where the profession is discredited because readers cannot be sure that what they are reading is not the result of ideological editing carried out by translation's equivalent of the nanny state. It seems that a simple though honest route we might take when translation becomes the site of ethical dilemma is to seek transparency. For we cannot deny that a translator has a responsibility to defend their ethical and ideological positions and beliefs, and if we admit this, then we must admit that their work as textual mediators cannot remain unaffected. Yet, if the translator decides to alter in anyway what he/she believes to be the literary worth of the source text, which in some cases must inevitably result in censorship, the reader has a right to know. A translator's note accompanying the translated text and describing the kind and level of deliberate translatorintervention (and reasons for it) would safeguard that relationship of implicit trust that runs between the translator and the reader. It 
would also go some way to preserving the integrity of the TT-ST relationship, where the target text would recognise itself as being a site of ideological conflict and holds itself accountable for the textual results of that conflict. Any attempt to establish blanket guidelines demarking right from wrong in issues such as this is doomed to failure, and each translator must assume the responsibility for his/her own textual and extra-textual actions; a translator's note describing the translator's intervention and reasons for this intervention would enable the translator to assume this responsibility and would also sensitize the reader to various political, ethical or ideological implications of the ST which otherwise may have remained concealed.

\section{Conclusion}

If we view translation from the perspective of deconstruction, important issues such as those discussed above - translator autonomy, creative responsibility, textual authority and ethical positioning - come to the fore and demand engagement. These issues would no doubt have presented themselves without the advent of deconstruction and are by no means inherently and exclusively linked to the latter. Yet, deconstruction makes issues such as this unavoidable; in challenging traditional forms of power and authority it destabilizes hierarchical power structures, such as that traditionally defining the translator's relationship to source text and source author, and demands that we consider the consequences of this subversion and its resulting realignment of power roles.

Deconstruction cannot be considered a general theory of translation. It does however present us with a form of critical practice which can be put to profitable use in the analysis of translation-related phenomena. Resistance to its methods may reflect the anxiety that deconstruction refuses to yield comfortable and 
conveniently packaged answers; indeed, every question aimed in its direction is met not with an answer but with a further question. Irigaray expresses this crisis in post-binary logic: "Where will the other spring up again? Where will the risk be situated which sublimates the subject's passion for remaining ever and again the same, for affirming himself ever and again the same?” (Irigaray 1985: 135). From an ideological perspective, deconstruction offers the researcher and the translator the possibility of authenticity insofar as it thwarts the easy apathy of essentialist viewpoints and encourages the subject to assume a responsible position vis-à-vis assumptions and beliefs inscribed in signifying systems. The challenge posed by deconstruction is therefore not so much that we accept the disappearance of the transcendental signified (God, truth, origin, authority); it is that we agree to continue in the epistemological search for meaning in full awareness that that meaning will remain elusive. But it is in its implied empowerment and validation of the translator as an active social and textual meaning producer that deconstruction is perhaps of most use as a framework for Translation Studies.

The discussion of the translator's dilemma above is just one in a whole series of implications resulting from the validation of the translator as social as well as textual player. Translation Studies would certainly benefit from more studies of this sort, where translators shed light for the rest of the translation community on areas of their experience which translation theory has yet to provide for. Deconstruction is one tool that translation scholars might want to employ in thinking about the problems linked to translation as a site of ideological conflict. In liberating the text from essentialist hierarchies and assumptions, deconstruction also liberates the translator who must assume an ethical position with regard to his/her creative rights and responsibilities as an active player in the production of meaning. Where being an active player implies deliberately intervening in the text, deconstruction can help provide 
a framework for thinking about the translator's dilemma. The opening discussion of différence highlights the fact that meaning is never self-identical and inevitably changes over time according to the new contexts in which it is (re)-produced.

Translation, like reading, produces meanings that cannot measure themselves against some origin because origin, as in the case of other transcendental signifiers, has ceased to have currency in a system where meaning is plural. If meaning is plural, no single translation or translation strategy can lay claim to total faithfulness. A translation is necessarily 'different' from its source text, but where the translator decides to intervene in the text by deliberately altering meanings, we might say that he/she is engaged in a form of 'non-safe' play and uses the site of translation to engage critically with ideas contextualized by the source text. Translation of this sort incorporates a form of commentary or critique and this overt position-taking, when clearly signaled by a translator's note, increases the integrity of the translated text. The textual results of deliberate intervention on the part of the translator are so closely related to the textual results of non-intentional intervention that one would be hard pressed to identify the point where what is deemed acceptable flows over into being unacceptable. If a translator reexamines the notion of faithfulness, assessing it in the context of deconstruction and ceasing to have to pretend faithfulness when we know that betrayal is inevitable, translator authenticity is heightened and the translated text is released from its subordinate position and is free enter into a dialectic relationship with ST that presages dialogue between two possibly conflicting ideologies and enriches the tapestry of interwoven texts. 


\section{References}

Abrams, H. 1976. Rationality and Imagination in Cultural History. Critical Inquiry 2. 3, 457-458. . 1977. The Deconstructive Angel. Critical Inquiry 3.3, 425438.

Arrojo, R. 1994. Fidelity and the Gendered Translator. TTR 7.2, 147-64.

. 1998. Revision of the Traditional Gap between Theory and Practice and the Empowerment of Translation in Postmodern Times. The Translator 4.1, 25-48. 2002. Writing, Interpreting and the Power Struggle for the Control of Meaning: Scenes from Kafka, Borges, and Kosztolanyi. In M. Tymoczko \& E. Gentzler (eds.), Translation and Power 63-79. Amherst \& Boston: Massachesetts University Press.

Barthes, R. 1970. S/Z. Paris: Editions du Seuil.

Bass, A. 1977. Translator's Introduction. Writing and Difference ixxx. London \& New York: Routledge.

Bauman, Z. 1995. Life in Fragments. Essays in Postmodern Morality. Oxford: Blackwell.

Belsey, C. 1980. Critical Practice. London \& New York: Routledge. Benjamin, W. 1955. The Task of the Translator. In R. Schulte \& J. Biguenet (eds.), Theories of Translation 71-82. Chicago, IL: Chicago University Press.

Chau, S. 1984. Hermeneutics and the Translator: The Ontological Dimension of Translating. Multilingua 3.2, 71-77.

Cixous, H. 1994. 'Preface' to The Helen Cixous Reader. In S. Sellers (ed.), The Helen Cixous Reader xv - xxiii. London: Routledge.

Culler, J. 1976. Saussure. London: Fontana. 
.1983. On Deconstruction. Theory and Criticism after Structuralism. London \& New York: Routledge.

Davis, K. 2001. Deconstruction and Translation. Manchester: St. Jerome Publishing.

De Man, P. 1982. The Resistance to Theory. In D. Lodge (ed.), Modern Criticism and Theory 335-410. London \& New Yoirk: Longman.

Derrida, J. 1978. Writing and Difference. London \& New York: Routledge.

. 1980. Des Tours de Babel. In R. Schulte \& J. Biguenet (eds.), Theories of Translation 218-227. Chicago, IL: Chicago University Press.

. 1985. Letter to a Japanese Friend. In D. Wood \& R. Bernasconi (eds.), Derrida and Difference. Warwick: Parousia.

1999. What is a Relevant Translation? In L. Venuti (ed.), The Translation Studies Reader 423-446. London \& New York: Routledge.

Eagleton, T. 1983. Literary Theory. Oxford: Blackwell. . 1988. Capitalism, Modernism and Postmodernism. In D. Lodge (ed.), Modern Criticism and Theory 385-398. London \& New York: Longman.

. 1990. The Ideology of the Aesthetic. Oxford: Blackwell. . (ed.). 1994. Ideology. London \& New York: Longman.

Eco, U. 1990. I Limiti dell'interpretazione. Milano: Bompiani. - 1995. Interpretazione e Sovrainterpretazione. Milano: Bompiani.

. 2003. Dire Quasi la Stessa Cosa. Esperienze di Traduzione. Milano: Bompiani.

Fish, S. 1980. Is There a Text in This Class? The Authority of Interpretative Communities. Cambridge, MA: Harvard University Press.

Hawkes, T. 1977. Structuralism and Semiotics. London \& New 
York: Routledge.

Hermans, T. 1999. Translation in Systems. Manchester: St. Jerome. Hillis, M. 1977. The Critic as Host. In D. Lodge (ed.), Modern Criticism and Theory 278-353. London \& New York: Longman.

Hirsch, E. 1976. Faulty Perspectives. In D. Lodge (ed.), Modern Criticism and Theory 254-263. London \& New York: Longman.

Irigaray, L. 1985. Speculum of the Other Woman. New York: Ithaca. Iser, W. 1978. The Reading Process: a Phenomenological Approach.

In D. Lodge (ed.), Modern Criticism and Theory 212-252.

London \& New York: Longman.

Jameson, F. 1991. Postmodernism, or the Cultural Logic of Late Capitalism. London \& New York: Verso.

Jones, F. 2004. Ethics, Aesthetics and Décision: Literary Translating in the Wars of the Yugoslav Succession. Meta 49.4.

Kristeva, J. 1980. Desire in Language. A Semiotic Approach to Literature and Art. Oxford: Blackwell.

Lane-Mercer, G. 1997. Translating the Untranslatable: The Translator's Aesthetic, Ideological and Political Responsibility. Target 9.1, 43-68.

Lewis, P. The Measure of Tranlsation Effects. In L. Venuti (ed.), The Translation Studies Reader 256-275. London \& New York: Routledge.

Maier, C. 1995. Towards a Theoretical Practice. Between Languages and Cultures: Translation and Cross-cultural Texts. Pittsburgh, PA: Pittsburgh University Press.

Moi, T. 1985. Sexual/Textual Politics: Feminist Literary Theory. London \& New York: Routledge.

Morton, S. 2003. Gayatri Chakravorty Spivak. London \& New York: Routledge.

Ovidio, C. 1996. The Exotic Space of Cultural Translation. In R. Alvarez, \& M. Carmen-Africa Vidal (eds.), Translation, 
Power, Subversion. Celevedon \& Philadephia: Multilingual Matters.

Pym, A. 1995. Doubts about Deconstruction as a Genral Theory of Translation. TradTerm 2, 11-18.

Said, E. 1994. Culture and Imperialism. London: Vintage.

Scruton, R. 1981. A Short History of Modern Philosophy. London \& New York: Routledge.

Sellers, S. 1994. The Helene Cixous Reader. London \& New York: Routledge.

Steiner, G. 1975. After Babel. Oxford: Oxford University Press.

Storey, J. 1994. Cultural Theory and Popular Culture. A Reader. Hemel Hempstead: Harvester Wheatsheaf.

Taylor, C. 1989. Sources of the Self. Cambridge: Cambridge University Press.

Tymoczkon, M. \& E. Gentzler (eds.). 2002. Translation and Power. Amherst \& Boston: Massachesetts University Press.

Vermeer, H. 1989. Skopos and Commission in Translational Action. In L. Venuti (ed.), The Translation Studies Reader 227-238. London \& New York: Routledge.

Venuti, L. 1998. The Scandals of Translation. London \& New York: Routledge.

Von Flotow, L. 1997. Translation and Gender. Manchester: St. Jerome.

Wright, E. 1984. Psychoanalytic Criticism. Theory in Practice. London \& New York: Routledge. 